Jurnal Maksipreneur, Vol.V, No. 1, Desember 2015 Hal. 117 - 133

\title{
ANALISIS KUALITAS PELAYANAN e-KTP MENGGUNAKAN METODE CUSTOMER SATISFACTION INDEX, METODE SERVICE QUALITY DAN IMPORTANCE PERFORMANCE ANALYSIS
}

\author{
Siti Noor Hidayati (datik_ng@yahoo.com) \\ Fakultas Ekonomi Universitas Proklamasi 45 Yogyakarta \\ Aris Puji Prasetyo (riri_airis@yahoo.com) \\ Alumni Fakultas Ekonomi Universitas Proklamasi 45 Yogyakarta
}

\begin{abstract}
This study attempts to analyzed levels of customer satisfaction on the quality of service and anything in the dimensions attributes the quality of services have to be prioritized to repairing in order to increase customer satisfaction. This study uses a Customer Satisfaction Index to measure the overall level of customer satisfaction.To sort the attributes do not satisfy the customer satisfaction levels by measuring the difference in performance levels using Service Quality. Then proceed with the measure by using Importance Performance Analysis to determine the attributes that have not been satisfying the customers. Results of this study showed that the majority of customers are satisfied with the services provided but not maximum yet. It can be seen from the results of customer satisfaction level testing using Customer Satisfaction Index (CSI) which is equal to 53,7\%. Based on testing using the Service Quality attributes improvements sequence starting from the attribute assurance because it has the greatest negative value. On testing using the Importance Performance Analysist (IPA), there are 8 service attributes that go into quadrant I, which means that there are 8 attributes that unsatisfactory customers and the service is not maximum yet.
\end{abstract}

Key words: Customer Satisfaction, Customer Satisfaction Index (CSI), Service Quality, Importance Performance Analysis (IPA)

\section{PENDAHULUAN}

Salah satu tugas pokok pemerintah adalah memberikan pelayanan kepada masyarakat. Oleh karena itu, organisasi pemerintah sering juga disebut sebagai “pelayan masyarakat”. Terwujudnya pelayanan yang baik bagi masyarakat sangat bergantung pada kemampuan aparat pelaksana dan tersedianya sarana pendukung yang memadai. Persoalan mendasar adalah sejauhmana aspirasi masyarakat telah terpenuhi dalam program-program pelayanan sesuai dengan kebutuhan masyarakat. 
Salah satu contoh bentuk pelayanan yang paling sering kita temui adalah pelayanan administrasi kependudukan. Pelayanan kartu tanda penduduk atau KTP, Kartu Keluarga atau KK adalah salah satu bentuknya. Kartu ini wajib dimiliki oleh setiap orang yang merasa menjadi warga Negara Republik Indonesia, sebagai bukti identitas keberadaannya.

Sejalan dengan perkembangan teknologi informasi dan komunikasi, Pemerintah telah menerbitkan UU Pelayana Publik No. 25/2009 sebagai tindak lanjut Kepres No. 88/2004 tentang Pengelolaan informasi Administrasi Kependudukan, di dalamnya diatur tatacara pelayanan adminsitarsi kependudukan. Peraturan ini diterbitkan guna mengantisipasi masalah tata cara pelayanan pendataan dan pendaftaran penduduk secara teliti dan modern berbasis computer.

Untuk melaksanakan undang-undang tersebut, selanjutnya Pemerintah Kota Yogyakarta, menerapkan sistem pendataan dan pendaftaran penduduk secara terpadu berbasis elektronik atau e-KTP. Sistem ini dikenal sebagai Sistem Informasi Manajemen Kependudukan, dimana petunjuk pelaksanaannya dilapangan mengacu pada Peraturan Mendagri Nomor 101 Tahun 2008.

Melalui kebijakan sistem informasi kependudukan yang diberlakukan secara nasional, diharapkan berbagai masalah yang berkaitan dengan pendataan penduduk dapat menjadi lebih baik yang pada gilirannya dapat lebih meningkatkan efektifitas dan efisiensi pelayanan pemerintah kepada publik, seperti pelayanan pembuatan Kartu Tanda Penduduk secara elektronis (e-KTP) maupun Kartu Keluarga (KK).

Sebagai tindak lanjut terbitnya Undang-UndangAdministrasi Kependudukan tersebut, Pemerintah Kota Yogyakarta, kemudian menerbitkan Peraturan Daerah (Perda) Nomor 09 Tahun 2009, tentang Penyelenggaraan Pendaftaran penduduk dalam kerangka Sistem Informasi Manajemen Kependudukan (SIMDUK) yang di dalamnya antara lain juga mengatur masalah mekanisme penerbitan e-KTP.

Sebagai pelaksana teknis peraturan daerah tentang penyelenggaraan pendaftaran penduduk dalam kerangka SIMDUK, Pemerintah Kota Yogyakarta melimpahkan kewenangannya kepada pemerintah dibawahnya yaitu pemerintah kecamatan untuk memberikan pelayanan kepada masyarakat dalam pembuatan dan 
penerbitan hal yang berkaitan dengan administrasi kependudukan seperti kartu tanda penduduk (e-KTP) maupun Kartu Keluarga (KK).

Hal yang seringkali ditemukan pada pelayanan publik untuk urusan administrasi kependudukan antara lain adanya kesenjangan antara harapan pelanggan/masyarakat terhadap kinerja pelayanan petugas urusan administrasi kependudukan e-KTP di instansi penyelenggara yang belum tercapainya kepuasan pelanggan/masyarakat terhadap kinerja petugas di instansi tersebut

Hal yang menjadikan kepuasan pelanggan/masyarakat sulit diwujudkan adalah sering kali persepsi produsen/petugas tentang harapan pelanggan/masyarakat tidak sejalan dengan apa yang diharapkan/ dipersepsikan konsumen/masyarakat tentang suatu produk (barang/jasa: pelayanan e-KTP). Selain itu, kepuasan juga merupakan hasil akumulasi dan proses yang berkepanjangan. Setiap saat tingkat kepuasan akan selalu berubah dan setiap transaksi/kontak antara produsen dan konsumen akan menjadi hal yang memberi pengaruh penting bagi kepuasan pelanggan (Rangkuti, 2002; Tjiptono (2012).

Kepuasan diartikan sebagai bentuk perasaan seseorang/evaluasi subjektif terhadap kesesuaian antara harapan dan kenyataan/pengalaman (Kotler, 1997 dalam Supranto, 2012). Definisi lain menyebutkan bahwa kepuasan adalah perbedaan yang dirasakan antara kenyataan dengan harapan (Atap, A.B, 2008). Sementara Gaspersz (2012), mengatakan bahwa kepuasan merupakan evaluasi positif dari dimensi pelayanan yang berbeda dilihat dari sudut pandang pelanggan Jadi, kepuasan atau ketidakpuasan adalah kesimpulan dari interaksi antara harapan dan pengalaman sesudah memakai jasa atau pelayanan.

Pada umumnya penelitian mengenai kepuasan pelanggan dilakukan dengan menggunakan survey (Tjiptono, 2012). Dengan metoda survey produsen/perusahaan akan memperoleh tanggapan atau umpan balik secara langsung dari pelanggan serta memberikan tanda (signal) positif bahwa produsen/perusahaan menaruh perhatian terhadap pelanggannya.

Dalam beberapa teori, kepuasan pelanggan dipengaruhi oleh beberapa hal, salah satunya adalah kualitas pelayanan. Kualitas adalah menjaga janji pelayanan 
agar pihak yang dilayani merasa puas dan diuntungkan (Ratminto \& Atik Septi Winarsih, 2005). Pelayanan adalah kegiatan-kegiatan yang tidak jelas namun menyediakan kepuasan masyarakat atau penduduk atau pemakai industri. Ia tidak terikat pada penjualan suatu produk atau pelayanan lainnya (Tjiptono, 2008). Sedangkan Kotler dan Bloom (dalam Nasution, 2010) berpendapat bahwa pelayanan adalah setiap kegiatan yang menguntungkan dalam suatu kumpulan atau kesatuan, dan menawarkan kepuasan meskipun hasilnya tidak terikat pada suatu produk secara fisik. Kualitas pelayanan juga dapat diartikan sebagai kegiatan pelayanan yang diberikan kepada seseorang atau orang lain, organisasi pemerintah/ swasta ( sosial, politik, LSM, dll) sesuai dengan peraturan perundang-undangan yang berlaku. Kualitas pelayanan sektor publik adalah pelayanan yang memuaskan masyarakat sesuai dengan standar pelayanan dan azas-azas pelayanan publik / pelanggan (Moenir, (2010).

Dalam mengukur suatu tingkat kepuasan konsumen terhadap produk jasa perlu dilakukan suatu analisis kualitas pelayanan yang dapat mempengaruhi tingkat kepuasan konsumen dengan membandingkan antara tingkat kepentingan (Importance) dengan kinerja (Performance) pelayanan, sehingga dapat diketahui sejauh mana tingkat perbaikan yang diinginkan oleh konsumen terhadap layanan yang mereka peroleh. Kualitas pelayanan ini ditentukan oleh beberapa dimensi kualitas pelayanannya yang dapat diuraikan ke dalam atribut-atribut penyusun dimensi tersebut. Dengan mengetahui dimensi kualitas pelayanan apa saja yang dapat mempengaruhi kepuasan konsumen. Dalam model penelitian Zeithaml (2000), kepuasan pelanggan dipengaruhi oleh variabel reliability (kehandalan), responsiveness (daya tanggap), assurance (jaminan), emphaty (empati), tangible (bukti fisik), product quality (kualitas produk), dan price (harga). Sedang menurut Pasuraman, dkk. (dalam Tjiptono, 2012), konsep kualitas pelayanan terdiri dari lima dimensi yaitu: tangible, reliability, responsiveness, assurance serta empathy. Menurut Oliver kepuasan adalah tingkat perasaan seseorang setelah membandingkan kinerja yang dirasakan dengan harapannya (J. Supranto, 2001). 
Banyak alat analisis untuk mengukur tingkat kepuasan pelanggan, di antaranya: a). Customer Satisfaction Index (CSI) merupakan analisis untuk mengetahui tingkat kepuasan pelanggan secara keseluruhan dengan memperhatikan tingkat kepentingan dari atribut - atribut produk atau jasa. Pada perhitungan tingkat kesesuaian dapat digunakan untuk mengetahui tingkat kepuasan pelanggan secara menyeluruh (Herni, 2005). Tingkat kesesuian dapat dijadikan kesimpulan bahwa konsumen merasa puas dengan kinerja pelayanan yang ada secara keseluruhan (Astuti, 2007). b). Metode Importance - Performance Analysis (IPA) merupakan metode yang digunakan untuk menganalisis kepuasan pelanggan terhadap suatu produk atau jasa. Teknik ini pertama kali dikemukakan oleh Martilla dan James pada tahun 1977 (Tjiptono, 2011), Pengukuran tingkat kepentingan dilakukan dengan cara pengukuran dari harapan pelanggan, sedangkan pengukuran tingkat kinerja diukur dari keadaan yang dirasakan oleh pelanggan (Maiyanti, 2008). Hasil pengukuran IPA digambarkan dalam Diagram Cartesius dengan empat kuadran. C). Service Quality $(S Q)$ mengukur kualitas pelayanan dengan menghitung seberapa jauh perbedaan atara kenyataan dengan harapan pelanggan atas layanan yang mereka terima. (Fandi Tjptono, 2008)

Berdasar dari uraian di atas maka dalam mengukur suatu tingkat kepuasan konsumen terhadap produk jasa perlu dilakukan suatu analisis kualitas pelayanan yang dapat mempengaruhi tingkat kepuasan konsumen sehingga perlu diteliti tentang kualitas pelayanan e-KTP dengan judul "Analisis Kualitas Pelayanan eKTP Di Kantor Kecamatan Tegalrejo, Kota Yogyakarta Menggunakan Metoda Customer Satisfaction Index, Importance Performance Analysis dan Metode Service Quality”

Dengan demikian permasalahannya: Bagaimana karakteristik masyarakat yang melakukan pendaftaran untuk membuat e-KTP di Kecamatan Tegalrejo Yogyakarta?. Bagaimana kepuasan masyarakat terhadap pelayanan Administrasi Kependudukan, khususnya e-KTP di Kantor Kecamatan Tegalrejo, Kota Yogyakarta 
Tujuan dalam penelitian ini adalah untuk mengetahui bagaimana karakteristik masyarakat yang melakukan pendaftaran untuk membuat e-KTP di Kecamatan Tegalrejo Yogyakarta serta bagaimana kepuasan masyarakat terhadap pelayanan Administrasi Kependudukan, khususnya e-KTP di Kantor tersebut?

Penelitian ini diharapkan dapat memberikan informasi, masukan, dan gambaran kepada Pemerintah Kecamatan Tegalrejo, Kota Yogyakarta tentang kepuasan masyarakat terhadap pelayanan Administrasi Kependudukan, khususnya e-KTP sehingga dapat merumuskan kebijakan proses penyelenggaraan pelayanan publik dengan lebih baik.

Berdasar uraian di depan dapat dijelaskan kerangka pikir dalam penelitian ini sebagai berikut: Untuk mengukur suatu tingkat kepuasan masyarakat terhadap produk jasa/pelayanan perlu dilakukan suatu analisis kualitas pelayanan yang dapat mempengaruhi tingkat kepuasan masyarakat pada tingkat kepentingan (Importance) masyarakat dan kinerja (Performance) pelayanan, sehingga dapat diketahui sejauh mana tingkat perbaikan yang diinginkan oleh masyarakat terhadap layanan yang diperoleh. Menurut Pasuraman, dkk. (dalam Tjiptono, 2012), konsep kualitas pelayanan terdiri dari lima dimensi yaitu: tangible, reliability, responsiveness, assurance serta empathy. Dengan demikian, kelima dimensi kualitas pelayanan tersebut merupakan tolokukur untuk mengukur kepuasan atau ketidakpuasan masyarakat terhadap kualitas pelayanan e-KTP di Pemerintah Kecamatan Tegalrejo, Kota Yogyakarta. Kerangka pikir tersebut dapat digambarkan sebagai berikut:

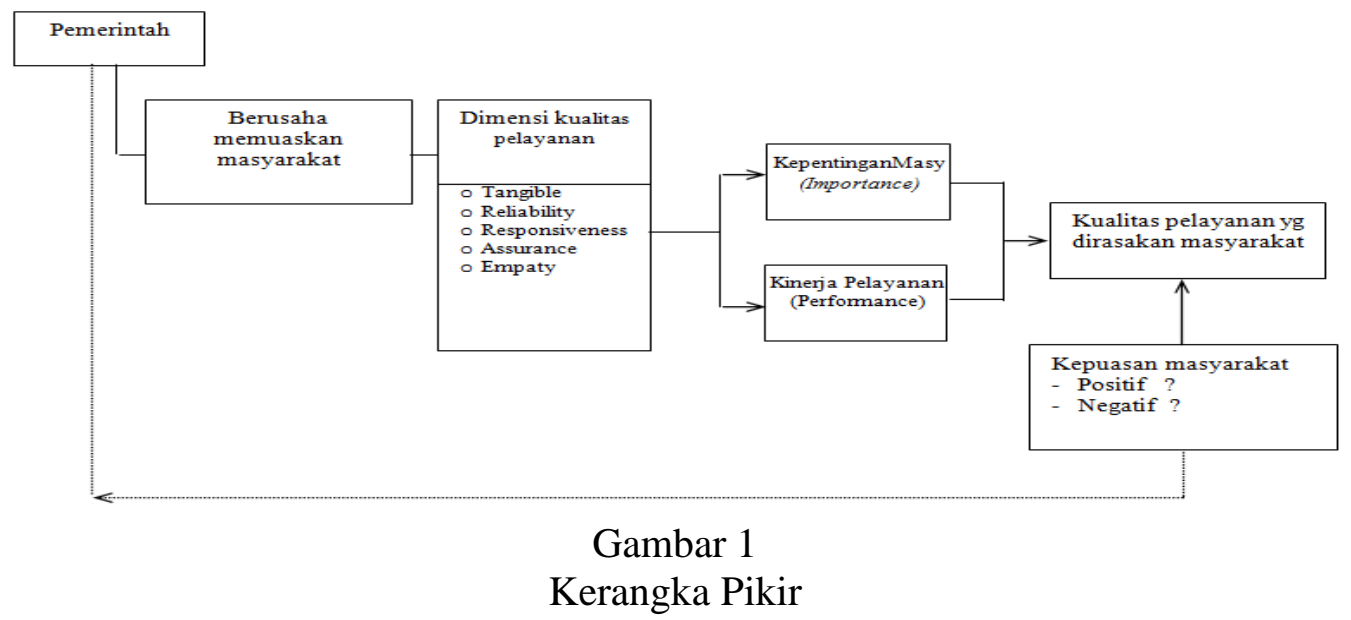




\section{METODE PENELITIAN}

Penelitian dilakukan di Pemerintah Kecamatan Tegalrejo, Kota Yogyakarta. Populasi dalam poenelitian ini adalah penduduk berdomisili di wilayah Kecamatan Tegalrejo yang telah wajib memiliki kartu tanda penduduk (KTP) dan pernah mengurus e-KTP. Jumlah sampel dalam penelitian ini 50 orang. Dengan metode pengambilan sampel convinience sampling.

Data yang diperlukan adalah data primer dari responden. Metode pengumpulan data digunakan Metode Angket, sedang metode pengukurannya dengan skala Likert yaitu skala yang digunakan untuk mengukur sikap, pendapat, persepsi dari seseorang tentang fenomena sosial (Sugiyono, 2009) Jawaban dari setiap item pernyataan disediakan 5 alternatif jawaban dan penilaian untuk masingmasing alternatif jawaban diberi bobot (skor): a). Pernyataan yang berkaitan dengan aspek kepentingan (Importance), pengukurannya adalah Sangat Penting (SP) skor 5, Penting (P) skor 4, Cukup Penting (CP) skor 3, Kurang Penting (KP) skor 2 dan Tidak Penting (TP) skor 1. b). Pernyataan yang berkaitan dengan aspek kinerja pelayanan (Performance), pengukurannya adalah Sangat Baik (SB) skor 5, Baik (B) skor 4, Cukup Baik (CB) skor 3, Kurang Baik (KB) skor 2 dan Tidak (TB) skor 1 .

Untuk mengukur tingkat kualitas pelayanan yang dapat mempengaruhi tingkat kepuasan masyarakat digunakan variabel/atribut dan indikator masing-masing variabel sebagai berikut: a). Tangible, (penampilan fisik) dengan indikator: kerapian dan kepantasan petugas dalam berpakaian, tata ruang kantor enak untuk dipandang, ruang tunggu yang bersih, aman dan nyaman, loket pelayanan yang bersih, aman dan nyaman, fasilitas tempat parkir kendaraan yang aman dan memadai, ketersediaan papan informasi, leaflet atau brosur. b). Reliability (kehandalan) dengan indikator kehandalan petugas dalam memproses pendaftaran dan pendataan penduduk, memberikan layanan secara tepat waktu, tepat prosedur dalam arti sederhana dan tidak berbelit-belit, memproses administrasi e-KTP, c) Responsiveness (rasa tanggap/kesigapan) dengan indikator kesigapan petugas untuk melayani keperluan masyarakat, melayani keperluan masyarakat, kejelasan dan 
kepastian waktu serta biaya yang diperlukan dalam memproses e-KTP, menangani keluhan masyarakat berkaitan dengan pengurusan e-KTP, kesiapsediaan petugas untuk senantiasa meluangkan waktunya melayani masyarakat. d). Assurance (Sikap petugas) dengan indikator perilaku petugas yang dapat dipercaya dalam melayani masyarakat, sikap profesional petugas dalam memproses administrasi e-KTP. Sikap simpatik petugas dalam melayani masyarakat, sikap dan perilaku petugas yang selalu mengutamakan kepentingan masyarakat. e). Emphaty (kepedulian petugas) dengan indikator ketulusan hati petugas ketika melayani masyarakat, kepedulian, keramahan serta perhatian petugas secara individual kepada pelanggan (masyarakat) petugas ketika melayani masyarakat, Waktu pelayanan yang dirasa tepat dan menguntungkan bagi semua pihak (petugas maupun masyarakat). Uji validitas dan uji reliabilitas terhadap semua angket (pernyataan) dari 5 (lima) variabel tersebut telah dilakukan dengan sampel 30 responden. Uji validitas dengan menghitung korelasi Pearson Product Momen (ryx). Hasil perhitungan semua item pernyataan pada masing-masing variabel diperoleh nilai ryx-hitung lebih besar dibanding r-tabel $(0,361)$ sehingga semua dinyatakan valid). Uji reliabilitas dengan menghitung alpha Cronbach, hasilnya nilai alpha kelima variabel semuanya di atas nilai 0,8 sehingga semua variabel dinyatakan reliabel.

Metode analisis data yang digunakan dalam penelitian ini adalah analisis kualitatif dan analisis kuantitatif sebagai berikut:

1. Untuk menganalisis karakteristik responden (karyawan) digunakan analisis kualitatif Yaitu analisis yang hanya menggunakan paparan sederhana, baik menggunakan jumlah data maupun persentase dengan membuat distribusi frekuensi (Suharsimi Arikunto, 2006).

2. Untuk menganalisis tanggapan responden (masyarakat) terhadap masingmasing variabel/atribut tangible, reliability, responsiveness, assurance serta empathy menurut kepentingan (Importance) dan kinerja (Performance) pelayanan digunakan Distribusi Frekuensi dan Rata-rata Hitung (Mean) . dengan inerval 0,8 dan ada 5 kriteria yaitu sangat rendah, rendah, cukup, tinggi, sangat tinggi. 
3. Untuk menganalisis kualitas pelayanan yang dapat mempengaruhi tingkat kepuasan masyarakat dalam pelayanan e-KTP digunakan analisis:

a). Customer Satisfaction Index (CSI) merupakan analisis untuk mengetahui tingkat kepuasan masyarakat secara keseluruhan.

$$
C S I=\frac{\sum T}{5\left(\sum I\right)} x 100 \%
$$

Keterangan:

$\mathrm{I}=$ rata-rata nilai skor kepentingan (Importance)

$\mathrm{T}=\mathrm{I} \times \mathrm{P}$

$\mathrm{P}=$ rata-rata nilai skor kinerja (Performance)

Nilai CSI maksimal $100 \%$. Nilai CSI $\leq 50 \%$ berarti kinerja pelayanan kurang baik. Nilai CSI $\geq 80 \%$ berarti masyarakat merasa puas terhadap kinerja pelayanan.

b). Kualitas layanan (Service Quality) sering disebut Servqual adalah seberapa jauh perbedaan atara harapan/kepentingan (Importance) dengan kenyataan/kinerja (Performance) atas layanan yang terima.

$$
\mathrm{Q}=\mathrm{P}-\mathrm{I}
$$

Keterangan: $\quad \mathrm{Q}=$ Quality Of Service (kualitas pelayanan)

$$
\begin{aligned}
& \mathrm{P}=\text { Performance } \text { (kinerja) } \\
& \mathrm{I}=\text { Importance } \text { (kepentingan) }
\end{aligned}
$$

Hasil perhitungannya dinyatakan sebagai "gap" kualitas pelayanan

c). Metode Importance - Performance Analysis (IPA) untuk mengukur kepuasan masyarakat yag hasil pengukurannya digambarkan dalam Diagram Cartesius dengan empat kuadran disebut ImportancePerformance Matrix (IPM). Pada teknik ini, responden diminta untuk menilai tingkat kepentingan dan kinerja pelayanan, kemudian nilai ratarata tingkat kepentingan dan kinerja tersebut dianalisis pada ImportancePerformance Matrix, dengan sumbu x mewakili kinerja/persepsi sedangkan sumbu y mewakili kepentingan/harapan. Tahapan pengukurannya sebagai berikut: 


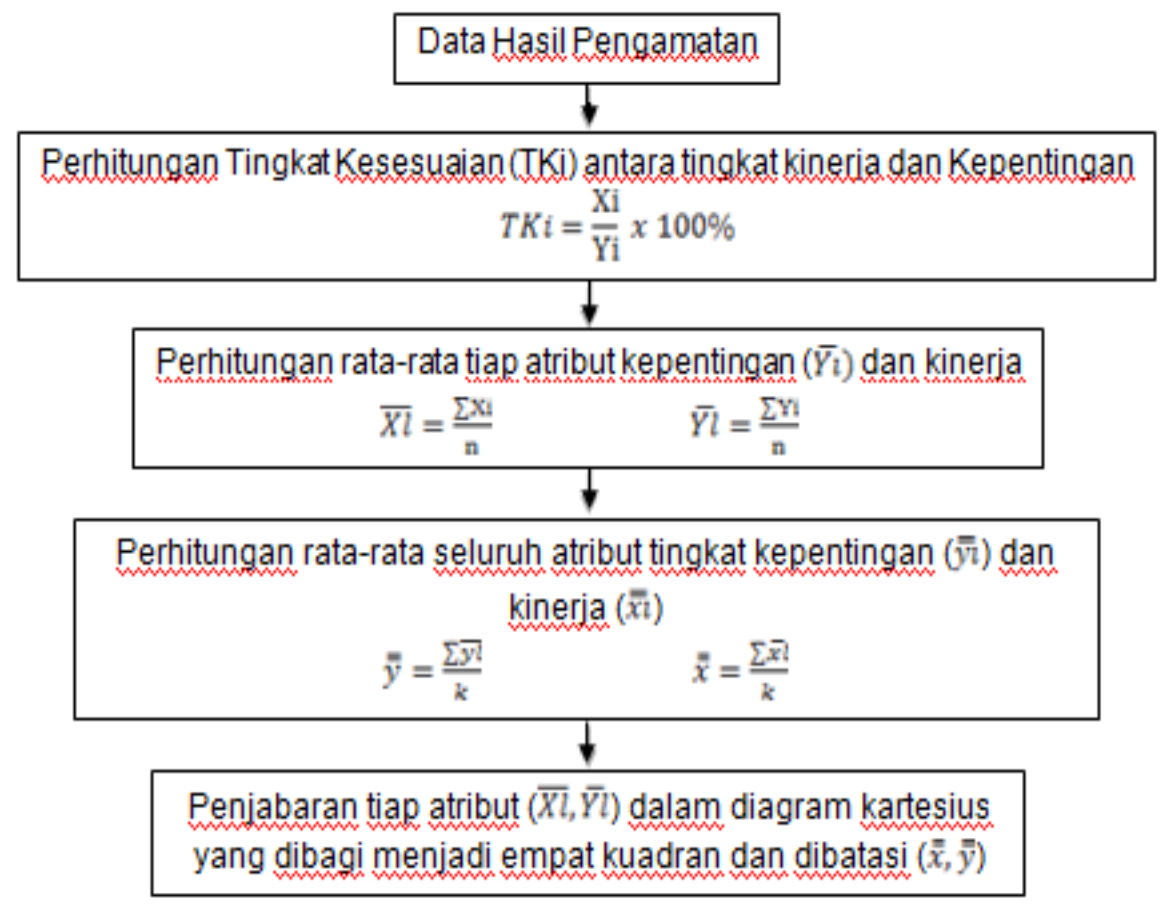

Pada perhitungan selanjutnya, nilai-nilai tingkat kepentingan dan kinerja yang didapat dimasukkan dalam diagram Importance-Performance Matrix (IPM)) berikut:

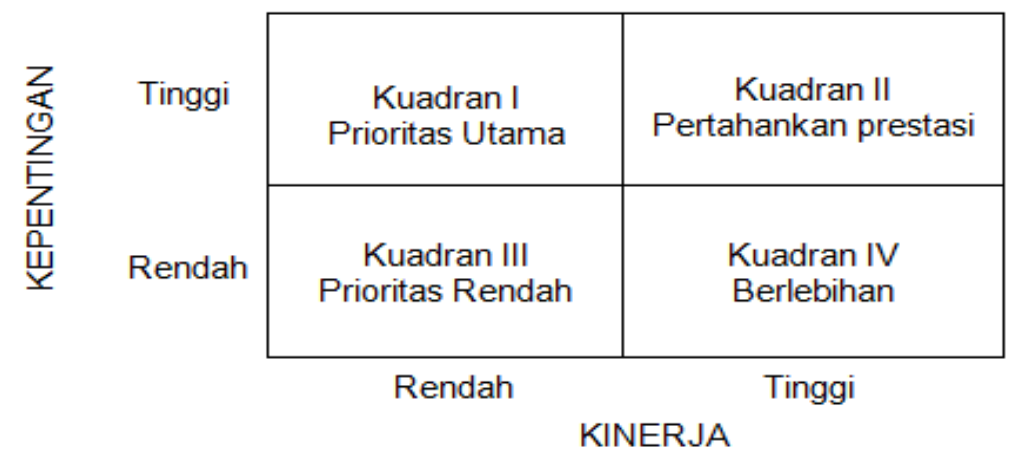

Adapun interpretasi dari kuadran tersebut adalah sebagai berikut:

1. Kuadran I. Prioritas Utama (Concentrate Here)

Pada kuadaran ini terdapat faktor-faktor yang dianggap penting dan diharapkan konsumen akan tetapi kinerja perusahaan dinilai belum memuaskan sehingga pihak perusahaan perlu berkonsentrasi untuk mengalokasikan sumber dayanya guna meningkatkan performa yang masuk pada kuadran ini. 
2. Kuadran II. Pertahankan Prestasi (Keep Up The Good Work)

Pada kuadaran ini terdapat faktor-faktor yang dianggap penting dan diharapkan sebagai faktor penunjang kepuasan konsumen sehingga perusahaan wajib untuk mempertahankan prestasi kinerja tersebut.

3. Kuadran III. Prioritas Rendah (Low Priority)

Pada kuadaran ini terdapat faktor-faktor yang dianggap mempunyai tingkat persepsi atau kinerja aktual yang rendah dan tidak terlalu penting dan atau tidak terlalu diharapkan oleh konsumen sehingga perusahaan tidak perlu memprioritaskan atau memberikan perhatian lebih pada faktor-faktor tersebut.

4. Kuadran IV. Berlebihan (Possibly Overkill)

Pada kuadaran ini terdapat faktor-faktor yang dianggap tidak terlalu penting dan tidak terlalu diharapkan oleh pelanggan sehingga perusahaan lebih baik mengalokasikan sumber daya yang terkait pada faktor tersebut kepada faktor lain yang lebih memiliki tingkat prioritas yantg lebih tinggi.

\section{HASIL PENELITIAN DAN PEMBAHASAN}

Pengumpulan data dengan angket dilakukan terhadap 50 responden masyarakat yang mengurus e-KTP di Kantor Kecamatan Tegalrejo Kota Yogyakarta. Namun, dari jumlah tersebut, hanya 39 responden yang hasil angketnya memenuhi syarat untuk di bahas lebih lanjut. 11 buah kuesioner lainnya tidak dapat di bahas karena kurang lengkap dan atau cacat. Setelah dianalisis diperoleh hasil sebagai berikut:

1. Karakteristik responden : Responden terbanyak adalah laki-laki yaitu 21 orang (54\%), usia antara 15-29 tahun yaitu 16 orang atau 42\%, status kawin yaitu 19 orang atau $48 \%$, pendidikan SMA/sederadjat yaitu 17 orang atau $44 \%$, pekerjaan wiraswasta yaitu 15 orang atau 38\% dan jenis KTP yang diurus perpanjangan KTP yaitu 16 orang atau $42 \%$.

2. Jawaban responden atas pernyataan semua indikator dari 5 variabel setelah direkap dan diolah datanya seperti dalam tabel berikut: 
Tabel 1. Rekapitulasi Data Hasil Penelitian atas Indikator Kepuasan Masyarakat dalam Pelayanan e-KTP beserta hasil olah data

\begin{tabular}{|c|c|c|c|c|c|}
\hline No. & $\begin{array}{c}\text { Indikator Yg Mempengaruhi } \\
\text { Kepuasan Pelanggan }\end{array}$ & $\begin{array}{l}\text { Kepentingan } \\
\text { (I) }\end{array}$ & $\begin{array}{l}\text { Kinerja } \\
(\mathrm{P})\end{array}$ & I x P & $\mathrm{Q}=\mathrm{P}-\mathrm{I}$ \\
\hline & & $\bar{Y}$ & $\bar{X}$ & $\bar{Y} \cdot \bar{X}$ & $\bar{X}-\bar{Y}$ \\
\hline 1 & $\begin{array}{l}\text { Kerapian dan kepantasan } \\
\text { petugas dalam berpakaian }\end{array}$ & 4,49 & 2,64 & 11,85 & $-1,85$ \\
\hline 2 & $\begin{array}{l}\text { Tata ruang kantor enak } \\
\text { untuk di pandang }\end{array}$ & 4,46 & 2,69 & 11,99 & $-1,77$ \\
\hline 3 & $\begin{array}{l}\text { Ruang tunggu yang bersih, } \\
\text { aman dan nyaman }\end{array}$ & 4,69 & 2,85 & 13,37 & $-1,84$ \\
\hline 4 & $\begin{array}{l}\text { Loket pelayanan yang aman, } \\
\text { nyaman dan bersih }\end{array}$ & 4,56 & 2,87 & 13,09 & $-1,69$ \\
\hline 5 & $\begin{array}{lrl}\begin{array}{l}\text { Fasilitas } \\
\text { kendaraan }\end{array} & \text { tempat } & \text { parkir } \\
\text { memadai } & \text { aman, }\end{array}$ & 4,15 & 2,80 & 11,62 & $-1,35$ \\
\hline 6 & $\begin{array}{l}\text { Ketersediaan papan } \\
\text { informasi, leaflet atau brosur }\end{array}$ & 3,85 & 2,77 & 10,67 & $-1,08$ \\
\hline 7 & $\begin{array}{l}\text { Kehandalan petugas dalam } \\
\text { memproses pendaftaran dan } \\
\text { pendataan penduduk }\end{array}$ & 4,00 & 2,69 & 10,76 & $-1,31$ \\
\hline 8 & $\begin{array}{l}\text { Kehandalan petugas } \\
\text { memberikan layanan secara } \\
\text { tepat waktu, tepat prosedur } \\
\text { dalam arti sederhana, tidak } \\
\text { berbelit-belit }\end{array}$ & 4,46 & 2,41 & 10,75 & $-2,05$ \\
\hline 9 & $\begin{array}{l}\text { Kehandalan petugas dalam } \\
\text { memproses administrasi } \\
\text { KTP/KK }\end{array}$ & 4,64 & 2,62 & 12,16 & $-2,02$ \\
\hline 10 & $\begin{array}{l}\text { Kesigapan petugas untuk } \\
\text { melayani keperluan } \\
\text { masyarakat }\end{array}$ & 3,69 & 2,85 & 10,52 & $-0,84$ \\
\hline 11 & $\begin{array}{l}\text { Kejelasan dan kepastian } \\
\text { waktu serta biaya yang } \\
\text { diperlukan dalam } \\
\text { memproses KTP/KK }\end{array}$ & 4,77 & 2,72 & 12,97 & $-2,05$ \\
\hline 12 & $\begin{array}{l}\text { Kesigapan petugas } \\
\text { menangani keluhan } \\
\text { masyarakat berkaitan dengan } \\
\text { pengurusan KTP/KK }\end{array}$ & 4,41 & 2,69 & 11,86 & $-1,72$ \\
\hline 13 & $\begin{array}{l}\text { Kesiapan petugas } \\
\text { meluangkan waktunya } \\
\text { melayani masyarakat }\end{array}$ & 4,31 & 2,46 & 10,60 & $-1,85$ \\
\hline 14 & $\begin{array}{l}\text { Perilaku petugas yang dapat } \\
\text { dipercaya dalam melayani } \\
\text { masyarakat }\end{array}$ & 4,59 & 2,64 & 12,12 & $-1,95$ \\
\hline 15 & $\begin{array}{l}\text { Sikap profesional petugas } \\
\text { dalam memproses } \\
\text { administrasi KTP/KK }\end{array}$ & 3,87 & 2,67 & 10,33 & $-1,20$ \\
\hline
\end{tabular}




\begin{tabular}{|c|l|c|c|c|c|}
\hline 16 & $\begin{array}{l}\text { Sikap simpatik petugas } \\
\text { dalam melayani masyarakat }\end{array}$ & 4,54 & 2,71 & 12,30 & $-1,83$ \\
\hline 17 & $\begin{array}{l}\text { Sikap dan Perilaku petugas } \\
\text { yang selalu mengutamakan } \\
\text { kepentingan masyarakat }\end{array}$ & 4,87 & 2,56 & 12,47 & $-2,31$ \\
\hline 18 & $\begin{array}{l}\text { Ketulusan hati petugas } \\
\text { ketika melayani masyarakat }\end{array}$ & 4,26 & 2,69 & 11,46 & $-1,57$ \\
\hline 19 & $\begin{array}{l}\text { Kepedulian, keramahan serta } \\
\text { perhatian petugas secara } \\
\text { individual kepada pelanggan }\end{array}$ & 4,13 & 2,85 & 11,77 & $-1,28$ \\
\hline 20 & $\begin{array}{l}\text { Waktu pelayanan yang } \\
\text { dirasa tepat dan } \\
\text { menguntungkan bagi semua } \\
\text { pihak (petugas maupun } \\
\text { masyarakat) }\end{array}$ & 4,64 & 2,59 & 12.02 & $-2,05$ \\
\hline & Jumlah & 87,38 & 53,77 & 234,61 & 33,61 \\
\hline & \multicolumn{1}{|c}{ Rata-rata: } & $=4,37$ & $X=2,69$ & - & 1,68 \\
\hline
\end{tabular}

Sumber: data hasil penelitian diolah, 2015

3. Berdasar Tabel-1 di depan dapat dianalisis tanggapan responden (masyarakat) terhadap masing-masing variabel/atribut tangible, reliability, responsiveness, assurance serta empathy.

4. menurut kepentingan (Importance) dan kinerja (Performance) pelayanan secara deskriptif sebagai berikut: Jika dianalisis rata-rata dari 5 variabel (20 indikator) rata-rata nilai skor kepentingan (Importance) $=4,4$ (sangat tinggi) dan kinerja $($ Performance $)=2,7$ (cukup) dengan demikian nilai kinerja harus ditingkatkan.agar semakin mendekati nilai kepentingan. Jika dianalisis secara parsial masing-masing variabel sebagai berikut:

- untuk variabel tangible responden dalam memjawab 6 indikatornya $\geq 48,72 \%$ responden menyatakan tingkat kepentingan Sangat Penting (SP) dengan rata-rata nilai skor 4,37 (Sangat Tinggi) dan $\geq 56,41 \%$ responden menyatakan tingkat kinerja Cukup Baik (CB) dengan rata-rata nilai skor 2,77 (Cukup Tinggi)

- untuk variabel reliability responden dalam memjawab 3 indikatornya $\geq 48,72 \%$ responden menyatakan tingkat kepentingan Sangat Penting (SP) dengan rata-rata nilai skor 4,37 (Sangat Tinggi) dan $\geq 46,15 \%$ responden menyatakan tingkat kinerja Cukup Baik (CB) dengan rata-rata nilai skor 2,57 (Rendah)

- untuk variabel responsiveness responden dalam memjawab 4 indikatornya $\geq$ $46,15 \%$ responden menyatakan tingkat kepentingan Sangat Penting (SP) dengan 
rata-rata nilai skor 4,37 (Sangat Tinggi) dan $\geq 48,72 \%$ responden menyatakan tingkat kinerja Cukup Baik (CB dengan rata-rata nilai skor 2,68 (Cukup Tinggi)

- untuk variabel assurance responden dalam memjawab 4 indikatornya $\geq 48,72 \%$ responden menyatakan tingkat kepentingan Sangat Penting (SP) dengan rata-rata nilai skor 4,47 (Sangat Tinggi dan $\geq 48,72 \%$ responden menyatakan tingkat kinerja Cukup Baik (CB) dengan rata-rata nilai skor 2,65 (Cukup Tinggi)

- untuk variabel empathy responden dalam memjawab 3 indikatornya $\geq 56,41 \%$ responden menyatakan tingkat kepentingan Sangat Penting (SP) dengan rata-rata nilai skor 4,34 (Sangat Tinggi) dan $\geq 61,54 \%$ responden menyatakan tingkat kinerja Cukup Baik (CB) dengan rata-rata nilai skor 2,71 (Cukup Tinggi)

5. Customer Satisfaction Index (CSI) merupakan analisis untuk mengetahui tingkat kepuasan masyarakat secara keseluruhan.

Dari Tabel 1 dapat diketahui $\quad \Sigma \mathrm{T}=234,61$ dan $\Sigma \mathrm{I}=87,38$

$$
C S I=\frac{\sum T}{5\left(\sum I\right)} \times 100 \%=\frac{234,61}{5(87,38)} \times 100 \%=53,7 \%
$$

Nilai CSI $=53,7 \%$ karena nilainya sudah di atas 50\% maka kepuasan masyarakat secara keseluruhan sudah termasuk kriteria cukup baik .

5. Kualitas layanan (Service Quality) sering disebut Servqual adalah seberapa jauh perbedaan atara harapan/kepentingan (Importance) dengan kenyataan/kinerja (Performance) atas layanan yang terima.

$\mathrm{Q}=\mathrm{P}-\mathrm{I} \quad \mathrm{Q}=$ Quality Of Service (kualitas pelayanan)

Hasil perhitungannya dinyatakan sebagai "kesenjangan (gap)" kualitas pelayanan.

Berdasar perhitungan pada Tabel 1 dapat dijelaskan bahwa semua nilai Q adalah negatif berarti tingkat kinerja pelayanan yang digambarkan dengan 20 indikator dari 5 variabel tangible, reliability, responsiveness, assurance dan empathy masih dibawah tingkat kepentingan masyarakat atau disebut masih ada kesenjangan (gap) negatip. Kesenjangan tertinggi pada indikator no. 17 termasuk dalam variabel Assurance yaitu sebesar - 2,31 dan kesenjangan terrendah pada indikator no.10 termasuk dalam variabel Responsiveness yaitu sebesar -0,84. Sedang jikka diambilo rata-rata dari semua indikator nilai kesenjangannya sebesar $, 1,68$. 
6. Metode Importance - Performance Analysis (IPA) untuk mengukur kepuasan masyarakat yag hasil pengukurannya digambarkan dalam Diagram Cartesius dengan empat kuadran disebut Importance-Performance Matrix (IPM) dengan sumbu X mewakili kinerja sedangkan sumbu Y mewakili kepentingan. Empat kuadran tersebut dibatasi oleh garis $\stackrel{\bar{X}}{X}$ dan garis $\stackrel{\bar{Y}}{Y}$.

Berdasar Tabel 1 dapat digambarkan IPM sebagai berikut:

Gambar Importance-Performance Matrix (IPM)

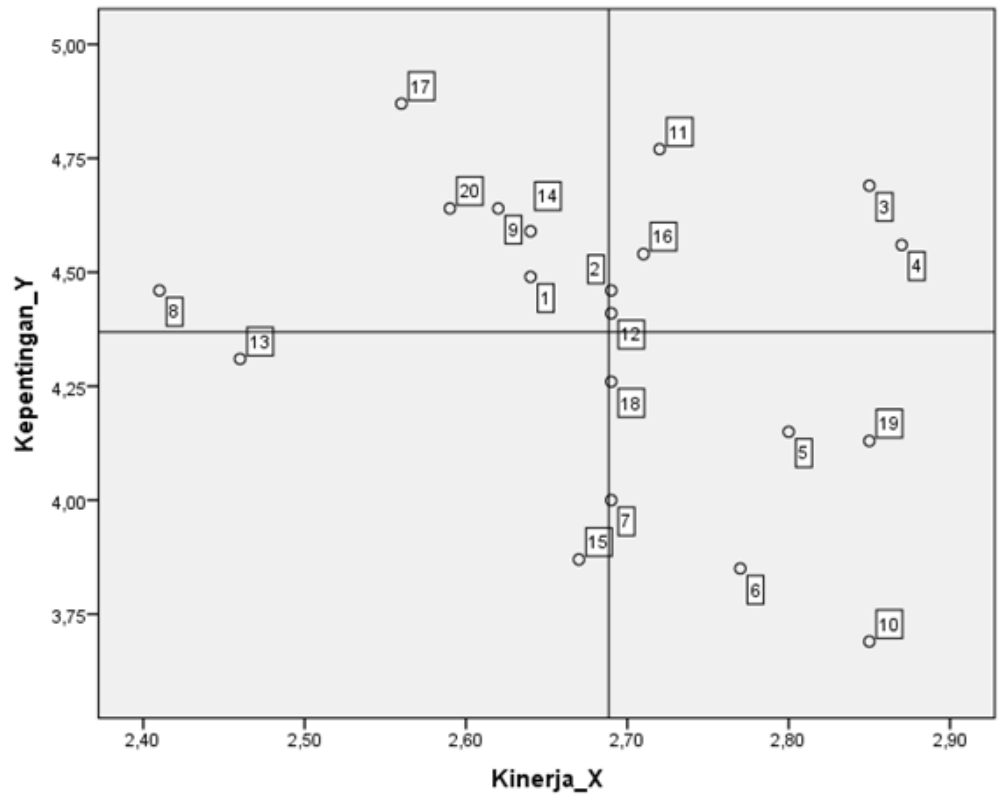

Adapun interpretasi dari kuadran tersebut adalah sebagai berikut:

a. Kuadran I. Prioritas Utama (Concentrate Here)

Indikator- indikator kualitas pelayanan yang berada pada kuadran I ada 8 indikator atau $40 \%$ yaitu indikator-indikator: nomor 1 , nomor 8 , nomor 9 , nomor 14 , nomor 17 dan nomor 20 serta nomor 2 dan nomor 12 (di garis batas Kuadran I dan II). Merupakan prioritas utama untuk ditingkatkan. Khusus indikator nomor 2 dan 12 karena ada di garis batas kuadran I dan II maka ditingkatkan akan lebih baik, atau paling tidak dipertahankan.

b. Kuadran II. Pertahankan Prestasi (Keep Up The Good Work)

Indikator- indikator kualitas pelayanan yang berada pada kuadran II ada 4 indikator atau $20 \%$ yaitu indikator-indikator: nomor 3, nomor 4, nomor 11, dan nomor 16 . Merupakan indikator yang perlu dipertahankan.

c. Kuadran III. Prioritas Rendah (Low Priority) 
Indikator- indikator kualitas pelayanan yang berada pada kuadran III ada 4 indikator atau $20 \%$ yaitu indikator-indikator: nomor 13 dan nomor 15 serta, nomor 7 dan nomor 18 (ada di garis batas Kuadran III dan IV. Indikator ini prioritasnya rendah atau dapat diabaikan. Khusus indikator nomor 7 dan 18 karena ada di garis batas kuadran III dan IV maka diabaikan atau sumberdaya yang ada dapat dialihkan.

d. Kuadran IV. Berlebihan (Possibly Overkill)

Indikator- indikator kualitas pelayanan yang berada pada kuadran IV ada 4 indikator atau 20\% yaitu indikator-indikator: nomor 5, nomor 6, nomor 10 dan nomor 19. Sumberdaya disini dapat dialihkan ke yang lebih diprioritaskan (kuadran 1).

\section{KESIMPULAN DAN SARAN}

Dari hasil penelitian dan pembahasan dapat disimpulkan:

1. Karakteristik responden : Responden terbanyak adalah laki-laki yaitu 21 orang (54\%), usia antara 15-29 tahun yaitu 16 orang atau 42\%, status kawin yaitu 19 orang atau $48 \%$, pendidikan SMA/sederadjat yaitu 17 orang atau 44\%, pekerjaan wiraswasta yaitu 15 orang atau 38\% dan jenis KTP yang diurus perpanjangan KTP yaitu 16 orang atau $42 \%$.

2. Nilai Customer Satisfaction Index (CSI) $=53,7 \%$ karena nilainya sudah di atas $50 \%$ maka kepuasan masyarakat secara keseluruhan sudah termasuk kriteria cukup baik .

3. Kualitas layanan (Service Quality) . Semua nilai $Q=$ Quality Of Service (kualitas pelayanan) negatif berarti tingkat kinerja pelayanan tingkat kepentingan masyarakat atau masih ada kesenjangan (gap) negatip dengan rata-rata - 1,68. Kesenjangan tertinggi pada indikator no. 17 ( dalam variabel Assurance) $=-2,31$ dan terrendah pada indikator no.10 (dalam variabel Responsiveness) $=-0,84$

4. Hasil Importance - Performance Analysis (IPA) yang digambarkan dalam ImportancePerformance Matrix (IPM): Di Kuadran I ada 8 indikator atau 40\%, prioritas utama untuk ditingkatkan, Di Kuadran II dipertahankan, Kuadran III diabaikan dan Kuadran IV berlebihan masing-masing ada 4 indikator atau $20 \%$.

Saran yang diajukan dalam penelitian ini adalah Kantor Kecamatan Tegalrejo harus meningkatkan kualitas pelayaan masyarakat khususnya dalam mengurus e-KTP, karena berdasar semua indikator kesenjangan antara kepentingan dan kinerja adalah negatif dan diprioritaskan pada indikator yang berada di Kuadran I. Kemudian sebaiknya 
diadakan penelitian lebih lanjut dengan responden yang lebih banyak dan dicermati kenapa gap antara kepentingan dan kinerja semua negatif dan terlalu besar.

\section{DAFTAR PUSTAKA}

Astuti, H. J. 2007. Analisis Kepuasan Konsumen (Servqual Model dan Important performance Analysis Model). Jurnal Media Ekonomi. Vol 7(1): 1-20

Atap, Adya Barata, 2008. Dasar-dasar Pelayanan Prima. Jakarta: Elex Media Komputindo

Gaspersz, Vincent. 2012, Manajemen Kualitas, PT. Gramedia Pustaka Utama, Jakarta.

Moenir, H.A.S., 2010, Manajemen Pelayanan Umum di Indonesia, Bina Aksara, Jakarta.

Nasution, N.M., 2010. Manajemen Jasa Terpadu (Total Service Management), Bogor: Ghalia Indonesia.

Rangkuti, Freddy, 2002. Measuring Consumer Satisfaction. Jakarta: PT Gramedia Utama.

Ratminto \& Atik Septi Winarsih, 2005. Manajemen Pelayanan, Yogyakarta: Pustaka Pelajar.

Supranto, J., 2012. Pengukuran Tingkat Kepuasan Pelanggan Untuk Menaikkan Pangsa Pasar. Jakarta: Rineka Cipta 